\title{
PENGARUH PENGGUNAAN TEKNIK BERMAIN DRAMA MELALUI TEATER TRADISIONAL RANDAI BERBASIS KEPERCAYAAN DIRI TERHADAP KEMAMPUAN APRESIASI DRAMA Oleh:
}

\author{
Ulil Amri' ${ }^{1}$ Vismaia S. Damaianti ${ }^{2}$
}

Universitas Pendidikan Indonesia

\begin{abstract}
This research based on finding that show a part of fifth grade students at SDN. 12 Sungai Lareh have low skills in playing drama and tend to have low self-confidence when they performing in front of the class. It caused by monotone form of learning that focused on the text books and they have lack of opportunity to appear in the public. As the result, students are less creative when they learning drama appreciation. This study aimed to describe the process and influence of drama play technique through Randai-based confidence traditional theatre to students appreciating drama ability. This research used pre-post quasi-experimental methods. Experiment class using drama play technique through Randai-based confidence, and the control class using direct instructions. Data analyzed with SPSS software version 21 and Ms. Excell 2007. The results found a significant influence on the use of drama play technique through Randai-based confidence to student appreciations drama ability. It can see from t test results showed that student ability in Randai class increase significantly compared to the control class. Based on this finding, the drama play technique through Randai-based confidence recommended to use as an alternative learning technique in elementary school.
\end{abstract}

Keywords: drama technique, Randai, Confidence, drama appreciation ability

\begin{abstract}
Abstrak: Penelitian ini dilatarbelakangi temuan yang menunjukkan sebagian siswa kelas V di SDN. 12 Sungai Lareh kurang terampil dalam bermain drama dan cenderung memiliki rasa percaya diri yang rendah saat tampil di depan kelas. Hal ini disebabkan pembelajaran apresiasi drama selama ini masih dalam bentuk percakapan monoton yang terfokus pada buku teks , dan kurangnya kesempatan siswa tampil di depan umum. Akibatnya siswa kurang kreatif dalam mengapresiasi drama. Penelitian ini bertujuan mendeskripsikan proses dan pengaruh penggunaan teknik bermain drama melalui teater tradisional Randai berbasis kepercayaan diri terhadap kemampuan apresiasi drama. Metode yang digunakan dalam penelitian ini metode kuasi eksperimen dengan desain prates-pascates. Kelas eksperimen menggunakan teknik bermain drama melalui teater tradisional Randai berbasis kepercayaan diri, sedangkan kelas kontrol melaksanakan pembelajaran dengan direct instruction. Analisis dilakukan menggunakan software SPSS. 21dan Microsoft Excell 2007. Hasil penelitian menunjukkan terdapat pengaruh yang signifikan penggunaan teknik bermain drama melalui teater tradisional Randai berbasis kepercayaan diri terhadap kemampuan apresiasi drama. Hal ini terlihat dari hasil uji t yang menunjukkan kemampuan apresiasi drama siswa di kelas eksperimen mengalami peningkatan signifikan dibanding kelas kontrol. Berdasarkan temuan tersebut, teknik bermain drama melalui teater tradisional Randai sangat direkomendasikan untuk digunakan dalam pembelajaran apresiasi drama di SD.
\end{abstract}

Kata Kunci: teknik bermain drama, Randai, kepercayaan diri, kemampuan apresiasi drama.

\section{PENDAHULUAN}

Pembelajaran bahasa bertujuan membantu siswa mengenal dirinya, budayanya, mengemukakan gagasan dan perasaan serta menggunakan kemampuan analitis dan imajinatif. Kemampuan tersebut dapat diasah melalui empat aspek keterampilan berbahasa dan bersastra; mendengarkan, berbicara, membaca, dan menulis (Depdiknas, 2006).

Namun realitas di lapangan pembelajaran bahasa terlalu menekankan

\footnotetext{
${ }^{1}$ Mahasiswa Pascasarjana Pendidikan Dasar UPI, Email: ulilamritanjung@gmail.com

${ }^{2}$ Dosen Universitas Pendidikan Indonesia
} 
pada keempat aspek berbahasa tersebut dan mengenyampingkan aspek kemampuan bersastra siswa. Padahal selain bersifat rekreatif, pembelajaran sastra juga bersifat membangun jiwa siswa. Melalui karya sastra siswa dapat memahami kehidupan, menanamkan karakter positif, pentingnya harga diri, dan kepuasan rohani.

Pembelajaran sastra di SD, khususnya pembelajaran drama membutuhkan kemampuan guru dalam merencanakannya dengan baik, dan memiliki ketertarikan kepada drama, baik dari segi sastra maupun pementasannya. Pembelajaran apresiasi dan ekspresi drama diharapkan dapat memberikan pengalaman belajar yang lebih bermakna bagi siswa. Hal ini sesuai dengan tujuan Kurikulum Tingkat Satuan Pendidikan (KTSP) yang tercantum dalam UU No. 20 Tahun 2003, yang menjelaskan bahwa siswa hendaknya, "dapat menikmati dan memanfaatkan karya sastra untuk memperluas wawasan, memperhalus budi pekerti, serta meningkatkan pengetahuan dan kemampuan berbahasa".

Menggunakan teknik bermain drama dapat melatih kompetensi membaca, menulis, menyimak, dan berbicara sekaligus meningkatkan kemampuan apresiasi drama siswa secara produktif dalam bentuk pementasan sederhana. Penggunaan teknik bermain drama juga dapat membantu siswa dalam menghayati karakter dan mendapatkan pengelaman emosi serta estetika yang dapat menunjang perkembangan kecerdasan emosi anak, Ampera (2010). Selain itu, Jones (dalam Hayes, 2008) menjelaskan bahwa pembelajaran menggunakan teater/drama anak dapat membantu siswa mengembangkan: (1) perkembangan fisik dan kinestetik, (2) pengembangan kemampuan bermain drama/teater, (3) pengembangan mental/kemampuan berpikir siswa, (4) pengembangan kemampuan personal/intra-personal, dan pengembangan kemampuan sosial/interpersonal. Pembelajaran dengan teknik berain drama juga dapat meningktakan rasa percaya diri, dan pemahaman siswa akan keberagaman, Singh (2004).

Ada beberapa penelitian sebelumnya yang menggunakan teknik bermain drama untuk meningkatkan kemampuan berbahasa siswa. Penelitian penggunaan teknik bermain drama untuk meningkatkan kemampuan berbicara siswa SD dilakukan oleh Ulas, A.H (2008) di Turki dengan judul Effects of Creative, Educational Drama Activities on Developing Oral Skills in Primary School. Ulas membandingkan penggunaan metode drama kreatif dengan pembelajaran dengan metode ceramah (direct instruction). Hasilnya, pembelajaran dengan menggunakan drama kreatif hasilnya jauh meningkat signifikan dibandingkan pembelajaran dengan metode ceramah. Penelitian lain di Indonesia dilakukan oleh Widia (2007) yang menggunakan teater tradional pagelaran Wayang Beber untuk meningkatkan kemampuan mengarang siswa SD. Pada penelitian berjudul "Penerapan Teknik Pagelaran Wayang Beber dalam Pengajaran Sastra untuk Meningkatkan Kemampuan Mengarang Siswa Sekolah Dasar" itu Widia menemukan meningkatnya hasil belajar kemampuan mengarang siswa SD setelah menerapkan teknik pagelaran Wayang Beber.

Dari beberapa penelitian tersebut belum ada yang menggunakan teater tradisional Randai dalam pembelajaran drama di SD. Randai merupakan salah satu teater tradisional Minangkabau yang menggabungkan drama, tarian berbasis gerakan silat, Kaba (cerita rakyat), dendang (nyanyian) dalam formasi berbentuk lingkaran dengan semangat dan irama yang rancak. Sebagai teater tradisional Randai selama ini hanya 
dimainkan oleh orang dewasa di malam hari, Rustiyanti (2013, hlm. 31).

Salah satu alternatif pembelajaran apresiasi drama anak di SD adalah dengan memasukkan Randai dalam proses pembelajaran yang diharapkan mampu untuk merangsang keaktifan belajar siswa, dan berpengaruh positif terhadap kemampuannya dalam mengapresiasi dan mengekspresikan drama. Sebagaimana temuan Cawthon dan Shasta (2011) yang menyatakan bahwa; art based instruction has been shown to increase student interest and motivation in learning. Selain meningkatkan minat dan motivasi belajar siswa, pembelajaran apresiasi drama anak di SD menggunakan teater tradisional Randai juga dapat melestarikan kekayaan kebudayaan daerah di tingkat dasar sehingga ke depannya anak lebih menghargai kekayaan budaya daerah yang dapat memperkuat identitas kebudayaan nasional. Tujuan penelitian ini adalah untuk mendeskripsikan teknik bermain drama melalui teater tradisional Randai berbasis kepercayaan diri terhadap kemampuan apresiasi drama, dan pengaruh penggunaan teknik bermain drama melalui teater tradisional Randai berbasis kepercayaan diri terhadap kemampuan apresiasi drama.
Ahli Randai dari University of Hawai' $i$ yang menjadikan Randai sebagai disertasinya, Pauka (2003) menjelaskan Randai sebagai sebuah pertunjukan. "Randai theater, the indigeneous Minangkabau theater form, is fundamentalist based on silat techniques and aesthetics. Besides martial arts, Randai features dance, acting, singing, instrumental music, and a unique type of percussion played by the dancers on a circle." Selain itu fungsi Randai menurut Pauka merupakan sebuah media hiburan dan pendidikan di nagari di Minangkabau

Ciri-ciri Randai menurut Rustiyanti (2010), yaitu: 1) para penari bergerak dalam lingkaran besar (12-15 orang), 2) sumber gerak penari galombang, bersumber dari pencak silat, 3) karakter tokoh diungkapkan melalui akting dan dialog, 4) ceritera disampaikan dalam adegan demi adegan, 5) dendang sebagai pembatas antara suatu adegan ke adegan berikutnya.

Unsur-unsur yang terdapat dalam Randai harus mencakup: 1) unsur cerita, 2) unsur gelombang, 3) unsur dendang, 4) unsur pelaku. Unsur tersebut dapat dilihat secara lebih jelas dalam diagram di bawah ini:

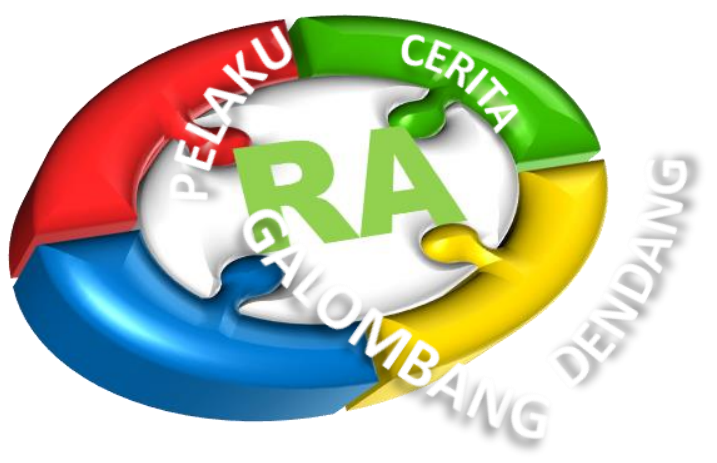

Gambar 1. Randai 
Musik pengiring dalam Randai terbagi menjadi dua, yaitu musik internal dan musik eksternal. Musik internal berupa bunyi-bunyian yang berasal dari anggota tubuh manusia, seperti tepukan tangan, petikan jari, tepuk dada, celana, siulan, hentakan kaki, dan sebagainya. Sedangkan musik eksternal merupakan suara alat musik atau instrumen dalam Randai seperti talempong, gendang, saluang, dan rebab, Rustiyanti (2014).

Bentuk pertunjukan Randai drama untuk anak yang digunakan hendaknya yang tidak rumit. Rancangan pementasan drama anak bertujuan membantu siswa memainkan peran dan memahami dasardasar bermain drama. Dalam pelaksanaannya guru dan siswa harus memilih naskah yang sesuai dengan materi pembelajaran, kemampuan siswa, ketersediaan sarana prasarana, dll. Selain itu yang harus diperhatikan peneliti dalam menggunakan teknik bermain drama dalam pembelajaran, yaitu jenis drama yang digunakan, naskah drama yang sesuai bahasa dan isinya dengan kemampuan siswa, fasilitator dari intervensi drama yang dilaksanakan, para ahli yang akan melatih fasilitator, dan penjelasan tentang pengukuran (measures) yang digunakan Mages (2008).

Teknis pembelajaran drama yang dipakai pada penelitian ini diadaptasi dari Rahmanto (2005) dan Sumiyadi (2013). Randai yang dilaksanakan berbasiskan kepercayaan diri agar siswa mampu mengapresiasi drama dengan maksimal. Percaya diri yang dimaksud disini menyangkut, keberanian siswa mengungkapkan pengalamannya dan melakukan refleksi,serta mengevaluasi latihan drama yang sudah mereka lakukan Rolfe, (2001). Hal ini bisa dilatih dengan memulainya di depan kelas. Karena tidak semua siswa memiliki kesempatan untuk menunjukkan kemampuan/bakatnya di depan teman-temannya di sekolah. Sebagaimana penjelasan Zimmerman (1996, hlm. 42) bahwa " feeling of self- confidence are very motivating to students who have not enjoyed many succes in school".

Adapun aspek-aspek yang terdapat dalam percaya diri yang diupayakan adalah: 1) sikap positif terhadap dirinya, 2) optimis, 3) objektif, 4) bertanggung jawab, 5) rasional , Ghufron dan Rini (2011).

Apresiasi drama merupakan kegiatan mengkaji unsur-unsur yang dikandung dalam sebuah drama dengan cara menghayati dengan sepenuh hati dan pikiran. Sebagaimana yang dijelaskan Endraswara (2011) bahwa, "apresiasi drama, yaitu upaya memahami drama dari aneka sisi. Apresiasi berarti merespons drama itu. Untuk menanggapi harus bisa masuk, menghayati drama itu secara suntuk". Tujuan apresiasi drama hendaknya mengacu pada empat konsep pembelajaran, yaitu; 1) belajar drama merupakan pembinaan, peningkatan kemampuan mengapresiasi drama, bukan proses pembentukan penguasaan pengetahuan tentang drama, 2) pembelajaran apresiasi drama dilakukan dengan memberi kesempatan seluasluasnya kepada siswa untuk berinteraksi secara langsung dalam menciptakan situasi yang mendorong siswa mendapatkan manfaat dari drama, 3) guru hendaknya merangsang terciptanya situasi dimana siswa memperoleh sendiri nikmat dan manfaat dari drama, 4) menghindarkan siswa dari proses yang bersifat mekanis, seperti terjebak dalam kegiatan menghafal dialog. Hal yang paling penting bagaimana siswa memeroleh kepuasan batin dalam pentas seni drama dan akhirnya mengenali, memahami, menghayati, menilai, dan menghargai drama sebagai sebuah karya sastra. (Syafi'i,1993).

\section{METODOLOGI PENELITIAN}

Penelitian ini menggunakan metode penelitian kuantitatif dengan metode kuasi eksperimen. Desain penelitian ini non 
equivalent group design dengan adanya prates dan pascates, serta treatment yang hanya diberikan pada kelas eksperimen (Sugiyono: 2013). Sampel penelitian merupakan siswa kelas V SDN. 12 Sungai Lareh dan SDN. 44 Sungai Lareh kecamatan Koto Tangah, Kota Padang. Instrumen yang digunakan berbentuk tes performa dan didukung oleh lembar observasi pembelajaran. Untuk melihat konsistensi penilai dilakukan validasi antar penilai menggunakan bantuan program SPSS Version 21 for Windows. Sedangkan untuk analisis data digunakan uji normalitas dan homogenitas. Untuk uji hipotesis dilakukan dengan uji t (uji perbedaan dua rata-rata). Hipotesis penelitian ini diajukan untuk melihat terdapatnya pengaruh penggunaan teknik bermain drama melalui teater tradisonal randai berbasis kepercayaan diri terhadap kemampuan apresiasi drama siswa.

\section{HASIL PENELITIAN DAN PEMBAHASAN}

\section{Proses pengunaan teknik bermain drama melalui teater tradisional Randai berbasis kepercayaan diri terhadap kemampuan apresiasi drama}

Dari pelaksanaan penelitian pada kelas eksperimen, proses pembelajaran berlangsung menggunakan teknik bermain drama melalui teater tradisional Randai berbasis kepercayaan diri yang diadaptasi dari teknik pembelajaran drama menurut Rahmanto (2005) dan Sumiyadi (2013), yaitu: 1) tahap Persiapan, terdiri atas: a) pelacakan pendahuluan : (1) memilih naskah randai, (2) memilih sutradara/pelatih, b) penentuan sikap praktis: (1) mempelajari naskah randai, (2) menganalisis (mengadaptasi) naskah randai, (3) penyajian randai dalam bentuk video/foto. 2) Tahap pelatihan, terdiri atas: a) mencari bentuk: (1) diskusi awal, (2) pengembangan randai, (3) diskusi lanjutan, b) pemantapan/latihan umum/praktik percobaan: (1) latihan gerakan randai, (2) latihan mengucapkan dialog, (3) akting, pagelaran/pementasan.

Tahap apresiasi pembelajaran dilaksanakan dalam empat tahapan, yaitu: (1) tahap menggemari, (2) tahap menikmati, (3) tahap mereaksi, dan (4) tahap produktif (mencipta). Masingmasing tahap berlangsung delapan kali pertamuan. Penilaian dilaksanakan pada hari terakhir tahap apresiasi berakhir (Ismawati: 2012)

Pada tahap menggemari siswa dihadapkan pada kegiatan membaca teks naskah drama secara mandiri, berkelompok, dan dibawah arahan guru. Untuk tahap menikmati dilanjutkan dengan membaca teks naskah drama secara berpasangan (berdialog), latihan memerankan tokoh dalam teks naskah drama, dan bereaksi positif terhadap rekannya. Tahap mereaksi menekankan pada kemampuan siswa berdiskusi, mengeluarkan pendapat tentang isi naskah, dan berpartisipasi dalam diskusi dengan baik, dan berlatih dengan disiplin mempelajari gerak Randai, akting, maupun teknik memainkan musik tradisional pengiring Randai. Pada tahap terakhir, siswa memerankan tokoh dalam naskah drama dengan lafal dan intonasi, mimik, dan eskpresi yang sesuai dengan naskah. Performa ini ditampilkan di depan para undangan dalam sebuah pementasan Randai drama.

Di kelas eksperimen pembelajaran berlangsung menggunakan pembelajaran direct instruction sebagaimana guru biasanya mengajar. . Guru melaksanakan pembelajaran melalui penjelasan (ceramah), tanya jawab, diskusi kelompok, dan penugasan. Naskah drama yang digunakan sama dengan naskah di kelas eksperimen.

2. Pengaruh penggunaan teknik bermain drama melalui teater tradisional Randai berbasis 
kepercayaan diri terhadap kemampuan apresiasi drama

Pengaruh penggunaan teknik bermain drama melalui teater tradisional Randai berbasis kepercayaan diri ini dapat dilihat dari perbandingan nilai kemampuan apresiasi drama pada hasil prates dan pascates kelas eksperimen dan kelas kontrol. Dari hasil analisis data prates kemampuan apresiasi drama siswa di kedua kelas didapatkan mean (rerata kelas) kelas kontrol 62,65 sedangkan pada kelas eksperimen 61, 84. Dengan standar deviasi sebesar 9,08 dan 10, 67. Dari perbandingan data mean dan standar deviasi tersebut dapat dilihat bahwa kemampuan apresiasi drama kedua kelas hampir sama. Setelah diuji normalitas dan homogenitas juga dapat dilihat bahwa kedua kelas berasal drai populasi yang berdistribusi normal homogen. Setelah diuji dengan uji t (tes perbedaan dua ratarata) semakin terlihat bahwa kedua kelas memiliki kemampuan apresiasi drama yang tidak terlalu berbeda.

Pada data pascates di kelas eksperimen ditemukan bahwa nilai pascates siswa pada tahap menggemari rata-rata naik tiga poin $(19 \%)$ dari prates sebelumnya. Untuk tahap menikmati naik dari menjadi $23 \%$. Pada tahap mereaksi rata-rata nilai siswa kelas eksperimen naik 23,45 , dan pada tahap produktif (mencipta) naik menjadi 25,5\%. Kenaikan signifikan terjadi pada kelas eksperimen yang menggunakan teknik berain drama berbasis kepercayaan diri melalui teater tradisional Randai ini dapat dilihat dari nilai siswa di kelas eksperimen yang mendapat nilai berkategori sangat tinggi dalam performanya 11 orang dari 31 siswa. (35\%). Tingginya atensi membaca siswa selain karena naskahnya baru dan menarik, juga disebabkan pemberian arahan dan motivasi dari guru kepada siswa agar latihan Randai yang akan dilaksanakan berjalan lancar dan mereka bisa tampil dengan percaya diri. Peningkatan ini sangat signifikan bila dibandingkan dengan kelas kontrol yang mengalami kenaikan pada tahap menggemari $6,65 \%$, pada tahap menggemari naik $8,5 \%$, pada tahap mereaksi naik $7,42 \%$, adapun pada tahap produktif/mencipta naik tipis $9,03 \%$. Dari hasil uji perbedaan rata-rata kedua kelas menggunakan uji t, diperoleh hasil sebagai berikut: 
Tabel 1. Uji Perbedaan Dua rata-rata (t-tes) Independent Samples Test

\begin{tabular}{|c|c|c|c|c|c|c|c|c|c|c|}
\hline & \multicolumn{2}{|c|}{$\begin{array}{l}\text { Levene's } \\
\text { Test for } \\
\text { Equality } \\
\text { of } \\
\text { Variances }\end{array}$} & \multicolumn{7}{|c|}{ t-test for Equality of Means } \\
\hline & & \multirow[t]{2}{*}{$\mathrm{F}$} & \multirow[t]{2}{*}{ Sig. } & \multirow[t]{2}{*}{$\mathrm{T}$} & \multirow[t]{2}{*}{ Df } & \multirow[t]{2}{*}{$\begin{array}{c}\text { Sig. } \\
(2- \\
\text { tailed })\end{array}$} & \multirow[t]{2}{*}{$\begin{array}{c}\text { Mean } \\
\text { Differen } \\
\text { ce }\end{array}$} & \multirow{2}{*}{$\begin{array}{c}\text { Std. } \\
\text { Error } \\
\text { Differen } \\
\text { ce }\end{array}$} & \multicolumn{2}{|c|}{$\begin{array}{l}95 \% \text { Confidence } \\
\text { Interval of the } \\
\text { Difference }\end{array}$} \\
\hline & & & & & & & & & Lower & Upper \\
\hline $\begin{array}{l}\text { Pascate } \\
\text { s }\end{array}$ & $\begin{array}{l}\text { Equal } \\
\text { variances } \\
\text { assumed } \\
\text { Equal } \\
\text { variances } \\
\text { not } \\
\text { assumed }\end{array}$ & .296 & $\begin{array}{r}.58 \\
8\end{array}$ & $\begin{array}{r}- \\
4.609 \\
\\
- \\
4.607\end{array}$ & $\begin{array}{r}63.85 \\
2\end{array}$ & .000 & $\begin{array}{r}- \\
13.9424 \\
6 \\
- \\
13.9424 \\
6\end{array}$ & 3.02622 & $\begin{array}{r} \\
19.9825 \\
9 \\
- \\
19.9882 \\
9\end{array}$ & -7.90233 \\
\hline
\end{tabular}

Dari tabel di atas dapat dilihat bahwa nilai signifikansi dari hasil penghitungan uji perbedaan dua rata-rata pascates lebih kecil dari 0,05 (sebesar $\frac{0,000}{2}$ $=0,000)$. Sehingga dapat dilihat adanya pengaruh signifikan penggunaan teknik bermain drama berbasis kepercayaan diri melalui teater tradisional Randai terhadap kemampuan apresiasi drama siswa.

\section{Pembahasan}

Secara umum pelaksanaan pembelajaran bahasa Indonesia dengan teknik bermain drama melalui teater tradisional Randai berbasis kepercayaan diri telah berjalan dengan baik. Kegiatan diawali pada tahap persiapan dengan memilih naskah dan pelatih Randai yang cocok dari sasaran Randai. Setelah selesai, guru memulai pembelajaran dengan menyajikan foto dan video yang memancing rasa ingin tahu siswa terhadap Randai. Siswa mengidentifikasi unsurunsur Randai berdasarkan apa yang dilihatnya. Selanjutnya siswa bertanya jawab dengan guru tentang sejarah, manfaat, dan teknik memainkan Randai. Siswa membaca naskah yang dibagikan guru secara mandiri, siswa bertanya jawab dengan guru mengnai hal-hal yang belum ia mengerti di dalam naskah. Guru kemudian membagi siswa menjadi beberapa kelompok untuk berdiskusi dan menelaah isi naskah untuk kemudian dipresentasikan dan ditanggapi oleh guru. Selanjutnya guru menugaskan siswa membaca kembali naskah di rumah.

Pada tahap pelatihan siswa melatih dialognya dalam kelompok, dilanjutkan dengan latihan gerak Randai, latihan memainkan musik tradisional, dan latihan berlakon. Latihan ini berlangsung lebih dari enam belas kali pertemuan. Dalam latihan selain mempelajari gerakan Randai (salam, kuda-kuda, lepoh, dll), berlakon (memerankan Malin Kundang, ibu, istrinya, dll), dan bermain musik (memainkan talempong dan gendang), siswa juga diberi arahan semangat agar lebih percaya dengan kemampuan dirinya dalam setiap kali latihan.

Latihan berlakon menekankan pada kemampuan siswa berdialg dengan lafal dan intonasi yang benar (meskipun rasanya latihan ini belum optimal dilakukan guru dan instruktur), 
memeragakan mimik wajah dan ekspresi tubuh yang pas dengan tokoh yang diperankan, serta mengetahui teknik blocking panggung khas Randai.

Pada saat pementasan, dengan hanya satu kali gladiresik, siswa bisa tampil memukau di hadapan para penonton, meskipun dalam catatan penilai sekaligus observer, masih banyak yang harus diperbaiki agar penampilan siswa lenih sempurna lagi. Kekurangan tersebut, terletak pada lafal dan intonasi siswaa yang terkadang masih terkesan terburuburu.

Setelah pementasan, siswa bersama guru dan instruktur melakukan refleksi atas pementasan dramanya. Dalam refleksi guru dan instruktur memberikan ucapan selamat juga koreksi atas kekurangan penampilan siswa.

Secara keseluruhan aktivitas pembelajaran berlangsung dengan baik. Kendala yang ada justru lebih bersifat teknis, seperti jadwal latihan, upaya guru memotivasi siswa, dan mengkomunikasikan latihan Randai dengan orang tua siswa. Kekurangan yang drama melalui teater tradisional randai berbasis kepercayaan diri mampu menciptakan pembelajaran drama yang penuh semangat dan percaya diri, sehingga layak direkomendasikan sebagai salah satu alternatif teknik pembelajaran drama di sekolah. Hal ini bersesuaian dengan pendapat Russel-Bowie (2013, hlm. 71) yang menyatakan bahwa guru perlu memberi siswa pengalaman belajar yang membari pengaruh perubahan positif terhadap sikap, rasa percaya diri, dan pengetahuan siswa, "educators need to present learning experience that will promote a positive change in students' attitude, confidence and knowledge in drama".

Berdasarkan hasil penelitian yang diperoleh terlihat bahwa kemampuan apresiasi drama siswa yang menggunakan teknik bermain drama melalui teater tradisional Randai berbasis kepercayaan diri mengalami peningkatan yang lebih baik dibandingkan siswa yang pembelajarannya berlangsung dengan strategi direct instruction. Berdasarkan analisis data rerata nilai prates

Tabel 2. Pretes Kemampuan Apresisasi Drama

\begin{tabular}{|c|c|c|c|c|}
\hline \multicolumn{5}{|c|}{ Nilai Prates Kemampuan Apresiasi Drama } \\
\hline Kelas & tahap 1 & tahap 2 & tahap 3 & tahap 4 \\
\hline kontrol & 65.766 & 61.44 & 60.54 & 63.063 \\
\hline eksperimen & 64.73 & 61.29 & 59.78 & 61.935 \\
\hline
\end{tabular}

lain terdapat pada lamanya waktu latihan yang memakan lebih dari 20 kali pertemuan. Hal ini disebabkan siswa masih awam dengan gerakan Randai.

Dilihat dari proses pembelajaran yang telah dilakukan, dibandingkan dengan pembelajaran biasa dengan direct instruction, pembelajaran dengan menggunakan teknik bermain drama melalui teater tradisional randai berbasis kepercayaan diri ini menunjukkan pengaruh yang berarti dalam meningkatkan kemampuan apresiasi drama siswa. Berdasarkan hasil observasi, pembelajaran menggunakan teknik berain kemampuan apresiasi drama pada tahap 1 (menggemari) rerata nilai siswa di kelas kontrol sebesar 65, 765 dan rerata nilai kemampuan apresiasi drama di kelas eksperimen sebesar 64,731, pada tahap 2 (menikmati) rerata nilai siswa di kelas kontrol sebesar 61,441 dan rerata nilai kemampuan apresiasi drama di kelas eksperimen sebesar 61,290, pada tahap 3 (mereaksi) rerata nilai siswa di kelas kontrol sebesar 60,54 dan rerata nilai kemampuan apresiasi drama di kelas eksperimen sebesar 59,78, sedangkan pada tahap 4 (produktif/mencipta) rerata nilai siswa di kelas kontrol sebesar 63,063 
dan rerata nilai kemampuan apresiasi drama di kelas eksperimen sebesar 61,935. Dari hasil keempat tahap tersebut menunjukkan bahwa kemampuan apresiasi drama siswa pada kelas kontrol dan kelas eksperimen saat prates masih sesuai dengan capaian masing-masing kelas. Secara lebih jelasnya nilai prates kemampuan apresiasi drama pada kedua kelas dapat dilihat pada tabel dan grafik di bawah ini:

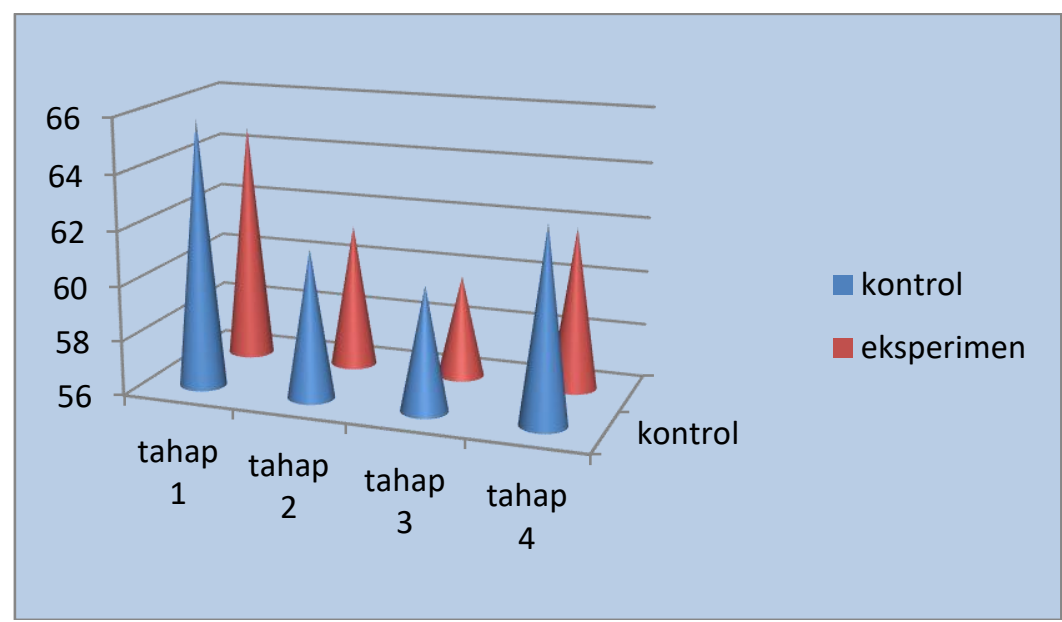

Gambar 1

Grafik Nilai Prates Kemampuan Apresiasi Drama

Kemudian pada kelas eksperimen diberikan teknik pembelajaran drama melalui teater tradisional berbasis kepercayaan diri dan kelas kontrol menggunakan pembalajaran sebagaimana biasa (direct instruction). Pada akhir setiap sebesar 70,359 dan rerata nilai kelas eksperimen sebesar 84,30, dan pada tahap 3 (mereaksi) rerata nilai kelas kontrol sebesar 67,657 sedangkan rerata nilai kelas eksperimen 83,225. Pada tahap 4 (produktif/mencipta) rerata nilai kelas

Tabel 3. Pascates Kemampuan Apresiasi Drama

\begin{tabular}{|c|r|r|r|r|}
\hline \multicolumn{5}{|c|}{ Nilai Pascates Kemampuan Apresiasi Drama } \\
\hline Kelas & tahap 1 & tahap 2 & tahap 3 & \multicolumn{1}{c|}{ tahap 4 } \\
\hline kontrol & 72.61 & 70.36 & 67.66 & 72.07 \\
\hline eksperimen & 84.086 & 84.3 & 83.23 & 87.1 \\
\hline
\end{tabular}

tahap pembelajaran apresiasi drama dilakukan pascates pada kedua kelas. Hasilnya, rerata nilai pascates kelas kontrol pada tahap apresiasi 1 (menggemari) naik menjadi 72,613, sedangkan pada kelas eksperimen meningkat menjadi 84,086. Pada tahap 2 (menikmati) rerata nilai kelas kontrol kontrol sebesar 72,072 dan rerata nilai kelas eksperimen sebesar 87,097. Hal ini berarti pada kedua kelompok terjadi peningkatan tetapi pada kelompok eksperimen peningkatan nilai kemampuan apresiasi drama lebih tinggi. Secara lebih jelas dapat dilihat pada tabel dan grafik di bawah ini: 


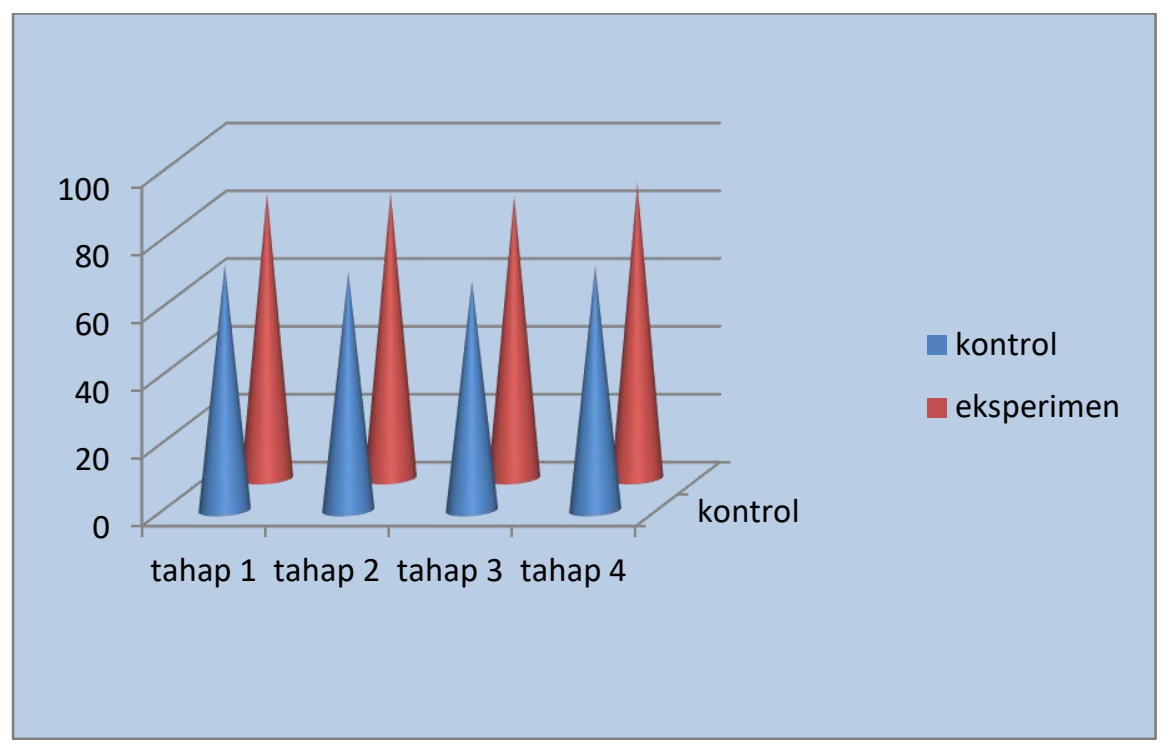

Gambar 2

Grafik Nilai Pascates Kemampuan Apresiasi Drama

Dengan melihat hasil pascates antar kedua kelompok terdapat selisih rerata skor yang cukup jauh, maka dapat ditarik kesimpulan, pebelajaran teknik bermain drama menggunakan teater tradisional Randai berbasis kepercayaan diri berpengaruh signifikan dalam meningkatkan kemampuan apresiasi drama siswa.

Peningkatan signifikan pada kelas eksperimen ini disebabkan pembelajaran dengan teknik bermain drama melalui teater tradisonal Randai ini mendukung hasil penelitian yang telah dilakukan Bogs, Mickel, dan Holtom, (2007) yang memperlihatkan peningkatan signifikan hasil belajar siswa menggunakan drama interaktif sebagai media pembelajaran siswa di kelas tinggi. Hasil penelitian ini juga sesuai dengan penelitian Widia (2007) yang menggunakan pagelaran wayang beber dalam meningkatkan kemampuan mengarang siswa. Perbedaannya terdapat hanya pada aspek berbahasa yang dinilai, yaitu kemampuan menulis. Hasil penelitian ini juga mendukung penelitian Putra (2012) yang menemukan peningkatan signifikan secara signifikan kemampuan apresiasi drama menggunakan model bengkel sastra.

\section{Keterbatasan Penelitian}

Penelitian ini tidak terlepas dari keterbatasan dan kelemahan meskipun telah diupayakan secara maksimal dan hati-hati. Keterbatasan itu perlu dikemukakan sebagai pertimbangan dalam menginterpretasi dan menggeneralisirkan hasil penelitian yang dicapai. Keterbatasan-keterbatasan tersebut antara lain:

1. Penelitian ini hanya dilakukan pada siswa semester 2 SDN.Sungai Lareh Koto Tangah Padang, sehingga belum dapat digeneralisasikan pada tempat lain yang meiliki karakteristik berbeda.

2. Kontrol terhadap karakteristik sampel hanya mencakup kemampuan apresiasi drama sehingga variabelvariabel lain yang mempengaruhi validitas internal penelitian seperti perbedaan kematangan, jenis kelamin dan tingkat kecerdasan lepas dari kontrol penelitian.

Berkenaan dengan keterbatasanketerbatasan hasil penelitian tersebut, diharapkan pengguna hasil temuan yang menerapkan maupun mengembangkan 
hasil penelitian ini lebih lanjut dapat memperhatikan hal-hal yang menjadi titik lemah dalam penelitian ini. Demikian juga kepada pengembang (peneliti) lain dapat memanfaatkan keterbatasan-keterbatasan ini sebagai masukan untuk menyempurnakannya.

\section{KESIMPULAN}

Berdasarkan analisis data dan pembahasan hasil penelitian tentang pengaruh penggunaan teknik bermain drama melalui teater tradisional Randai berbasis kepercayaan diri di SDN. Sungai Lareh Kecamatan Koto Tangah Kota padang, maka dapat ditarik kesimpulan sebagai berikut:

1. Proses penggunaan teknik bermain drama melalui teater tradisional Randai berbasis kepercayaan diri terhadap kemampuan apresiasi drama siswa dilaksanakan dalam dua tahap, tahap pertama persiapan yang terdiri atas pelacakan pendahuluan dan penentuan sikap praktis, serta tahap kedua yang terdiri atas mencari bentuk, latihan umum, dan pagelaran.

2. Terdapat pengaruh yang signifikan dalam penggunaan teknik bermain drama melalui teater tradisional Randai berbasis kepercayaan diri. Hal ini dapat dilihat dari rata-rata peningkatan masing-masing kemampuan apresiasi siswa di kelas kontrol dan eksperimen. Peningkatan rerata kemampuan apresiasi drama di kelas eksperimen lebih tinggi daripada rerata kemampuan apresiasiasi drama siswa di kelas kontrol dengan pembelajaran direct instruction.

\section{DAFTAR PUSTAKA}

Ampera, T. (2010). Pengajaran sastra: Teknik mengajar sastra anak berbasis aktivitas. Bandung: Widya Padjadjaran.

Boggs, J. Mickel, A. Holtom, B. (2007). Experiental learning through interactive drama: an Alternative to student role plays. Journal of Management Education, 31 (6), DOI:
$10.1177 / 1052562906294952$ hlm. 832-858.

Cawthon, S. W. Kathryn D dan Shasta I. (2011). Activating student engagement through drama-based instruction. Journal for Learning through the Arts, 7 (1), eScholarship University of California hlm.1-29.

Depdiknas. (2006). Kurikulum teknologi satuan pendidikan. Jakarta:

Kemdikbud.

Endraswara, S. (2011). Metode pembelajaran drama. Yogyakarta: CAPS.

Ghufron, N dan Rini, R.S (2011). Teoriteori Psikologi. Jogjakarta: Ar-Ruz Media.

Haynes, K. 2008. What drama education can teach your child. (0n-line), tersedia

http://www.education.com/magazine/ article/What_Drama_Education_Can Teach/. Diakses 25 Oktober 2015.

Ismawati, E. 2012. Pembelajaran apresiasi drama Jawa di sekolah; Problema dan solusinya. Makalah Proceeding, tersedia (on-line) : http://journal.unwidha.ac.id/index.ph p/proceeding/article/view/233

Mages, W..K. (2008). Does creative drama promote language development in early childhood? A review of the methods and measures employed in the empirical literature. Review of Educational Research, 78 (1). DOI: 10.3102/0034654307313401, hlm. 124-152

Pauka, K. (2003). Silat - based Randai theater of West Sumatra makes Its U.S.debut. Journal of Asian Martial Arts, 9 (12), ISSN. 1057-8358. Media Pub.Co, hlm. 49-65.

Putra, A. W. (2012). Penerapan model bengkel sastra untuk meningkatkan kemampuan apresiasi drama mahasiswa. Bandung:UPI Tesis tidak diterbitkan. 
Rahmanto, B. (2005). Metode pengajaran sastra. Yogyakarta: Penerbit Kanisius

Rolfe, L. (2001) The factors wich influence student teachers' confidence to teach dance. European Physical Education Review, 7 (2), ISSN 1356-336X, hlm. 157-175.

Russel-Bowie,D. (2013). A tale of five countries: Background and confidence in preservice primary teachers in drama education accross five countries. Australian Journal of Teacher Education, 38 (7), DOI: 10.14221/ajte.2013v38n7, hlm. 5874.

Rustiyanti, S. (2010). Menyingkap seni pertunjukan etnik di Indonesia. Bandung: Sunan Ambu STSI Press.

Rustiyanti, S dkk. (2013). Tari Minang aesthetic in Randai arts: Textualcontextual analysis. International Journal of Humanities and Social Sciences, 2(4), ISSN: 2319-393X, hlm. 31-42.

Rustiyanti, S. (2014). Musik internal dan eksternal dalam kesenian Randai. Jurnal Resital ISI Yogyakarta, 15 (2), ISSN: 2085-9910, hlm. 152-162.

Sugiyono. (2013). Metode penelitian pendidikan: Pendekatan kuantitatif, kualitatif, dan $R \& D$. Bandung: CV. Alfabeta

Sumiyadi. (2013). Sanggar sastra: pengalaman artistik dan estetik sastra. Bandung: Prodi Bahasa SPS UPI.

Syafi'i, I. (1993). Terampil berbahasa Indonesia; petunjuk guru bahasa Indonesia. Jakarta: Depdikbud

Widia, Ida. (2007). Penerapan teknik pagelaran Wayang Beber dalam pengajaran sastra untuk meningkatkan kemampuan mengarang siswa Sekolah Dasar. UPI: Bandung. Tesis tidak diterbitkan Singh, A. (2004). Humanising education: Theatre in Pedagogy. Contemporary Education Dialogue, 2 (1). DOI. 10.1177/09731849040020010, hlm. 53-84.

Ulas, A.H. (2008). Effects of creative, educational drama activities on developing oral skills in primary school. American Journal of Applied Science, 5 (7), ISSN 1546-9239, hlm. 876-880.

Zimmerman, B. Kitsantas, A. (1996). Self regulated learning of motoric skills: The roles of goal setting and self-monitoring. Journal of Applied Sport Psychology, vol. 8, hlm. 69-84. 